\title{
EVOLUTION OF THE GOVERNING LAW FOR LOAN AGREEMENTS OF THE WORLD BANK AND OTHER MULTILATERAL DEVELOPMENT BANKS
}

\author{
By John W. Head* \\ I. INTRODUCTION
}

\section{The Issues and Their Importance}

What is the governing law for loan agreements entered into by the World Bank' and other multilateral development banks (MDBs) in carrying out their public sector lending? That question was first definitively addressed about thirty-five years ago. ${ }^{2}$ This article examines the question anew, against the backdrop of recent developments in practice, especially at the newest of the MDBs, the European Bank for Reconstruction and Development (EBRD).

The issue is important because the legal rules that govern the loan agreements of the World Bank and the other main MDBs-the Asian Development Bank (ADB), the Inter-American Development Bank (IDB), the African Development Bank (AFDB) ${ }^{5}$ and

\footnotetext{
* Professor of Law, University of Kansas. The author wishes to thank friends at the European Bank for Reconstruction and Development, especially Mr. Gerart Sanders, and the World Bank for contributing ideas and suggestions for this article. The author also wishes to thank Mr. Aron Broches for his helpful comments on an earlier draft of the article. Some of the observations in the article draw on the author's experience as a consultant to the EBRD at various times in the years 1993-1995. All views expressed here, however, are the author's and not necessarily those of the EBRD or its staff. Research support from the University of Kansas is gratefully acknowledged.

'The World Bank consists of two legally separate, but closely related, institutions: the International Bank for Reconstruction and Development (IBRD), established in 1945 following the Bretton Woods conference, and the International Development Association (IDA), established in 1960 to provide more concessional financing for the less economically developed countries, many of which were at that time gaining political independence. A more encompassing term, "World Bank Group," refers to the IBRD and IDA, plus the International Finance Corporation, established in 1956 to engage in private sector financing, the Multilateral Investment Guarantec Agency (MIGA), establislued in 1988 to provide guarantees against various types of noncommercial risks faced by foreign private investors in developing countries, and the Intemational Centre for Settlement of Investment Disputes (ICSID), established in 1966 to provide conciliation and arbitration facilities for the settlement of disputes related to transnational investments. See IBrajus F. I. Sulliata. Tul:

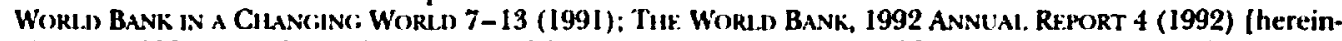
after WB 1992 REP(okT]. For descriptions of the World Bank and the World Bank Group, see generally SilliLTA, supra. See also John W. Heat, Supranational Law: How the Move Toward Multilateral Solutions Is Changing the Character of "International" Law, 42 KAN. L. Rt:. 605, 629, 642 (1994) [hereinafter Supranational Law]; John W. Head, Environmental Conditionality in the Operations of International Development Finance Institutions, 1 KaN. J. L. \& PUR. Pol.'y 15, 16-17 (1991) [hereinafter Conditionality].

Aron Broches, Intemational Iegal Aspects of the Operations of the World Bank, 98 Rrcunil. DEs Cours 297 (1959 111). See further text at and note 17 infra.

"The ADB, headquartered in Manila, was established in 1965. See Acirikntist FstABLISHING; THF: ASIAN Devilopment BaNk, Dec. 4, 1965, 17 UST 1418, 571 UNIS 123 (entered into force Aug. 22, 1966). The ADB started functioning in December 1966. AstaN DevtilopMeNT BANK. 1994 ANNUAl. Rrport (inside front cover) (1995) [hereinafter ADB 1994 RF.PORT]. For general infornation about the history and operations of the ADB, see DICK WILSON, A BA.vk fOR HAIF THE: Wokl,1) (1987).

'The IDB, headquartered in Washington. D.C., was established in 1959. See AC :REEMENT ESTAHI ISIING: TIIE: Intek-AmERICAN DEveicol'mint Bank, Apr. 8, 1959, 10 UST 3029, 389 UNTS 69 (entered into force Dec. 30, 1959), amended Jas. 28, 1964, 21 UST 1570, amended Mar. 31, 1968, 19 UST 7381, amended Mar. 23, 1972, TLAS No. 7437. For information about the history and operations of the IDB, sec generally INTER-AMrikJCAN

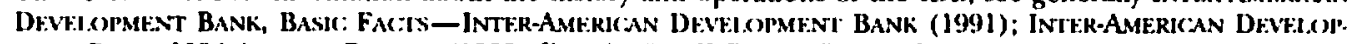
MFNI BANR. 1994 ANNIAI. RH:IORT (1995) [hereinafter IDB 1994 REPORT].

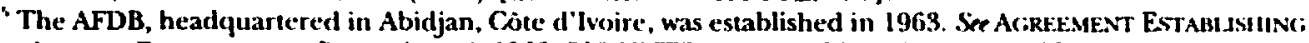
Tit: African Detelopatint BANk, Aug. 4, 1963, 510 UNTS 3 (entered into force Sept. 10, 1964). For current

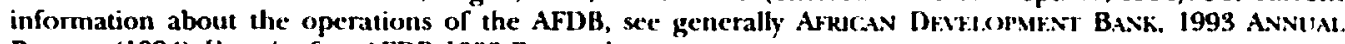
R:.PORT (1994) [hereinafier AFDB 1993 Rt.PRI].
} 
the EBRD which in turn bear on the likelihood that the loans made under those agreements will be repaid and, ultimately, on the stature of the institutions themselves and the support they receive from the international community. Most of the MDBs, especially the World Bank, are coming under increasing criticism on many fronts. ${ }^{7}$ For example, some political leaders in the United States and other relatively rich industrialized countries with large stakes and heavy influence in the World Bank ${ }^{H}$ have urged that financial support for it be sharply reduced; ${ }^{9}$ and some leaders in less economically developed countries have advocated that loans from the World Bank not be repaid. ${ }^{10}$

\footnotetext{
"The EBRD, headquartered in London, was established in 1990. SeeAciRtEMENT ESTABI.ISIIING, TIIt: EUROPEAN BANK fOR Riconstruction ANI DevelopMint, May 29, 1990, 29 ILM 1077 (1990) [hereinafter EBRD Chak. TER] (entered into force Mar. 28, 1991). For general information about the history and operations of the

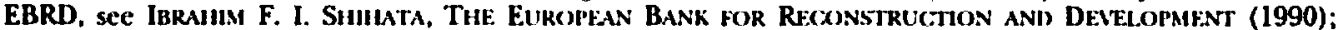
Head, Supranational Lat, supra note 1, at 635-49; EUROP'AN BANK FOR RECONSTRU(TTION AND DEAtLOPMENT, 1994 ANNUAl. REIORT (1995) [hereinafier EBRD 1994 RE:ORT].

${ }^{2}$ See, e.g., Patricia Adams, The World Rank's Finances: An Intemational SEl Crisis, Pol.'y Anal.rsis No. 215 (Cato Institute), Oct. 3, 1994, at I (claiming that the World Bank "must be shut down" because "its irresponsible lending exposes Western taxpayers to a possible World Bank bailout on a scale comparable to the U.S. savings-and-loan bailout"); Carol Barton, Stnutural Adjustment: Deadhy "Development," Gi.obal Anvocates Bul... Oct. 1994, at 1, 2-5, 27, 31, 33-35 (criticizing the World Bank for its structural adjustment lending). For a more comprehensive assessment of the World Bank, see generally BRuce. Rici, Moktcinsinc; THE. EAkTHTil: World Bank, Environmintal. Impovirisiment, AND the Crists of Devilopment (1994). Rich asserts that World Bank lending has caused "profound human and ecological damage," and expresses the hope that readers will exert political pressure to either "radically reinvent the institution or stop funding it." Id. at xiixiii. Many analyses, of course, run in the other direction. See, e.g., Henry Owen, The World Bank: Is 50 Years Enough?, FOREIGN Afr., Sept.-Oct. 1994, at 97, 108 (concluding that criticisms from both right and left are incorrect and that the World Bank has a good record).

"Under the weighted voting system that applies in each of the MDBs discussed herein, voting power is concentrated in the Group of Seven (G-7) industrialized states (the United States, Japan, Germany, France, the United Kingdom, Canada, and Italy), closely reflecting the capital subscriptions held by those states. See TtJ: WORI.D BANK, 1994 ANNUAI. RHPORT 189-86, 201 (1994) [hereinafter WB 1994 REPORT] (showing aggregated voting powers as $44.4 \%$ and $47.4 \%$ for $G-7$ member countries of the IBRD and the IDA, respectively); intr.rnational. Financie Cokjoration, Annual. RkPOkT 1994, at 114-15 (1994) [hereinafter IFC 1994 Rf: PORT] (showing aggregated G-7 voting power as 53.1\% in the IFC); ADB 1994 RtrokT, supra note 3, at 14243 (showing aggregated G-7 voting power as $45.4 \%$ in the ADB); IDB 1994 REPOKT, supra note 4, at 128-29 (showing aggregated G-7 voting power as $44.1 \%$ in the IDB); AFDB 1993 REPORT, supra note 5, at 106-09 (showing aggregated G-7 voting power as $24.6 \%$ in the AFDB); EBRD 1994 Rr:PORT, supra note 6, at 52 (showing aggregated $G-7$ voting power as $56.7 \%$ in the EBRD).
}

"See, e.g.. Jim Lobe, U.S.Aid: Clinton's 1996 Budget Holds Line on Forrign Aid, Inter Press Service, Feb. 6, 1995, available in LEXIS/NEXIS, MDEAFR Library, CURNWS File (noting efforts by some Republican leaders of Congress in early 1995 to reduce U.S. financing of IDA); Jim Lobe, Finance: World Bank Sof-Loan Facility in Limbo, Inter Press Service, Jan. 5, 1996, available in L.EXIS/NEXIS, WORI.D Library, Al L.NWS File (noting the success of those efforts as of late 1995 and the dim prospects for future U.S. funding for IDA); Rose Umoren, World Bank, NGOs Trade Blame as IDA Slips Away, Inter Press Service, May 30, 1995, available in I.EXIS/NEXIS, NEwS Library. INPRES File (quoting a World Bank official as saying that future U.S. support for IDA "will be very minimal" and suggesting that the battle to secure IDA's future has been virtually lost); Patricia Feeney, Fair Shares for the Rich, Tut GuARIstan, Mar. 11, 1995, at 24, available in I.EXIS/NEXIS, MDEAFR Library, CURNWS File (noting similar pressures in Canada and Britain to reduce aid programs); Nicholas Eberstadt \& Clifford M. Lewis, Privalize the World Bank, WAl.J. St. J., June 27, 1995, at A12 (proposing partial elimination of the World Bank and privatization of the remainder). For a description of some past efforts in the U.S. Congress to reduce financial support for the World Bank, see Jonathan Earl Sanford, U.S. Policy Toward the Multilateral Development Banks: The Role of Congress, 22 Gios. WASl1. J. INT'1. L. \& BoxN. 1, 42-45 (1988).

'"Ser, e.g., Bulgarian Refining Board Proposes Plan, Fin. TIMEs E. Eur. Enfrey Rfir. (London), Sept. 1992. available in LEXIS/NEXIS. WORI.1) Library, Al.1.NWS File (reporting that Bulgaria's Neftochim refining company proposed suspending payments on a World Bank loan in order to strengthen the company's finances); Raul Ronzoni, Unuguay: Leftists Struggle to Unite Before 1994 Elections, Inter Press Service, Nov. 16, 1993, available in id., CURNwS File (noting that one member party in Uruguay's left-wistg coalition espoused "non-payment of the foreign debt"). Perhaps the most public high-level threat in this regard came in 1987, when Romania threatened to suspend repayment of its $\$ 1.9$ billion debt to the World Bank. See Jan Krcmar, Ronania Threatens to Suspend World Bank Debt Repayment, Reuters, Dec. 3, 1987, available in id., ALINWS File. Several instances of such suspensions have in fact occurred in recent years. See, e.g., Panama Holding Debs Talks in New York - Banker, Reuters, Mar. 21, 1995, availuble in id. (noting that "Panama halted all foreign debt payments in 1987, but [later] reached restructuring agreements" with lenders); Congo Pays OOf World Bank Loan Amears, Reuters, July 1, 1994, available in id. (noting the Congo's arrears of about $\$ 100$ million to the World Bank); Zambia: Government Pays 50m Dollars Amears to World Bank, British Broadcasting Corp., Feb. 11, 1992, available in id. 
In a commercial setting, such antagonistic circumstances as these (criticisms from shareholders and threats of default by borrowers) would prompt a lender to ensure that the legal agreements under which it extends loans are expressly made subject to a specified body of law that would prove favorable - or at least not unfavorable - to the lender in case of default or dispute. Indeed, the importance of including a clear and favorable choice-of-law provision in any international contract is a common theme in international commercial and financial practice."

Applied to the World Bank and the other MDBs, this consideration suggests that their loan agreements should include a definitive provision making the agreement subject to a system of law that the lender could count on to protect it in case the borrower defaults on payment or challenges the agreement in a way that makes dispute settlement and enforcement necessary. In particular, an MDB would probably want the governing law provisions in its loan agreements to specify some system of law other than that of the borrower. Otherwise, the lender (the MDB) could face numerous problems.

For example, if World Bank loan agreements could be construed as being subject to local law, some public sector borrowers (states and state-owned enterprises) ${ }^{12}$ might try claiming that obligations undertaken in such an agreement - for example, the obligation

(discussing Zambia's arrears to the World Bank); Nicaraguan Officials to Meet with World Bank, Reuters, July 24, 1991, available in id. (noting Nicaragua's arrears to the World Bank); Penu Craves Big Writedoun; Citi to Lend \$I Billion Bridge, AM. BANKER-BONI BUYYR, Nov. 30, 1992, available in LEXIS/NEXIS, BANKING Library, ALLNWS File (noting Peru's arrears to the World Bank). For a list of World Bank member countries behind in their loan payments to the World Bank as of mid-1994, see WB 1994 Ri:PORT, supra note 8, at 168.

"I "[A] clause which specifies the applicable law is essential" in drafting an international contract with an cye to resolving any potential disputes between the parties. Jay M. Vogelson, Dispule Resolution, Enforcement and Temination of Agreements, Goveming Law, Choice of Fonum, and Jurisdition, in NEGotiatinc: AND StRUCtURING. Intervational. Commercial. Transar:tions 109, 110 (Shelly P. Battram \& David N. Goldsweig eds., 1991). In case the contract specifies arbitration as the means of settling disputes thereunder, "it is important for the arbitration clause itself to designate the law applicable to the arbitration." Id. at 117. A choice-of-law clause provides certainty and predictability to the application and construction of the terms of an agreement and to the enforcement of the rights and remedies established thereunder. Raymond M. Aucrback, Governing Law Issues in Intemational Financial Transadions, 27 INI'L. LAw. 303, 308 (1993). Such certainty and predictability are important in the case of loans for the simple reason that, "once the lender has parted with its funds, it will be extremely vulnerable." $I d$. at 916. For other references to the importance of including clear provisions on governing law in international commercial and financial agreements, see Michael Gruson, Governing-Law Clauses in Intemational and Interstate Loan Agreements-New York's Approach, 1982 UNIV. It.1. L. REv. 207, 207;

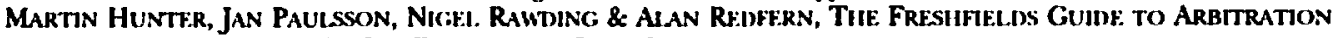
AND ADR 31 (1993) [hereinafter Fufsititis.ns GuIDE].

I" Both the IBRD and the IDA may make loans to member states, state-owned enterprises or private entities. If a loan is made directly to a state-owned enterprise or a private entity, the IBRD is required (and the IDA is permitted) to have the loan guaranteed by the government of the member state in which the project is being carried oul. See ARTICI.tS of AGREEMENT Of TII: INTERNATIONAL. BANK FOR RF.CONSTRUCTION AND Devil.opment, July 22, 1944, Art. III, \$4(i), 60 Stat. 1440, 2 UNTS 134, amended Dec. 16, 1965, 16 UST 1942. 606 UNTS 294 [hereinafter IBRD CiLARTE. (entered into force Dec. 27, 1945), reprinted as amended Dec. 17, 1965, in 1 Basic: Documents of Intriknational. Economic: LaW 427 (Stephen Zamora \& Ronald A. Brand

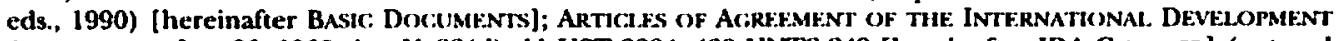
Association, ]an. 26, 1960, Art. V. \$2(d), 11 UST 2284, 439 UNTS 249 [hereinafter IDA CIAARTER] (entered into force Sept. 24, 1960). Because the purpose of the IDA is to alleviate the burden of external financing on poorer countries, IDA loans (technically called "credits") have traditionally been made only to member states, instead of to stateowned enterprises or private entities. Aron Broches, The World Bank, in INTERNATIONAI. Financial. Law-Lending, Capital. Transfrers ann Institutions 251, 262 n.72 (Euromoney Publications,

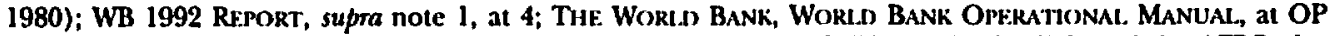
7.00 92, 13 n.4 (loose-leaf, July 1994) [hercinafter WB Orlik. MAN.]. The ADB, the 1DB and the AFDB also make all or nearly all of their loans to states and state-owned enterprises. See John W. Head, International Contracting Opportunities Under Projects Financed by the World Bank and Related Institutions, INI'1. CONTRACT ADVIsoR, Spring 1995, at 41, 44 [hereinafter Contracting]. The EBRD is required by its charter to make $60 \%$ of its loans to the private sector (that is, to entities that are neither (1) owned or controlled by the state, nor (2) enjoying the benefit of a guarantee by the state or a state-owned entity), although it has had some difficulty in reaching that target because of changed political circumstances in its countries of operation. See Head, Supranational Law, supma note 1, at 647-48. See also Matthew H. Hurlock, New Approaches to Economic Development: The World Bank, the EBRD, and the Negative Pledge Clause, 35 HARv. INT'L. L.J. 345, 372 (1994). The IFC lends exclusively to the private sector. See IFC 1994 RFPORT, supra note 8, at 1. 
to follow certain procedures for the procurement of goods ${ }^{13}$ or to refrain from applying loan proceeds to payment of taxes on goods imported into the country for use in projects financed by the World Bank ${ }^{14}$ - are void because of inconsistency with local law. If, on these grounds, the borrower were to stop following the World Bank's procurement guidelines or to use loan proceeds to pay import tariffs on project-related goods, financial support for the World Bank itself could crumble. ${ }^{15}$

Beyond that, if World Bank loan agreements were subject to local law, the validity of the agreements themselves might, in extreme circumstances, be thrown into question. In a borrowing country where the executive and judicial branches of government are engaged in sharp political rivalry, for instance, a citizens' group might persuade a court to declare a loan agreement with the World Bank to be null and void on grounds that it is inconsistent with the state's public policy-for example, the policy of protecting the state's rights of sovereignty and self-determination. Indeed, a legal attack on the validity of a loan agreement might even be made by the executive branch itself, especially in a borrowing member country that has experienced a radical change in leadership, resulting in a refusal to repay the World Bank loan. ${ }^{16}$

\section{A Changing Institutional Landscape}

These questions, as they relate to the governing law for World Bank loan agreements, were addressed in 1959 when Aron Broches, then the General Counsel of the World Bank, presented a set of Hague Academy lectures. ${ }^{17}$ In presenting what is generally regarded as the traditional World Bank view, Broches posited (1) that loan agreements of the World Bank with member states were governed by international law, ${ }^{18}$ and (2) that its loan agreements with state-owned entities were not governed by international law but nonetheless "excluded" the operation of municipal law."

\footnotetext{
" World Bank loan agreements typically require that goods and services for a project financed with World Bank funds be purchased in accordance with the bank's procurement guidelines, which generally require that internationally competitive bidding procedures be followed. WB OPE.R. MAN., supra note 12, at OP 7.01, ๆ3 (July 1994). For an overview of World Bank procurement guidelines, see THE. WORLD BANK. BIDDING FOR Contratiss in Worl.d Bank Financifn Projticts 10 (n.d.). See also Broches, supra note 12, at 256 n.32. Other MDBs typically impose the same requirements. See Head, Contrating, supra note 12, at 47.

"She International. Bank for Reconsthugtion ani) Developmint, General. Conditions applacable.

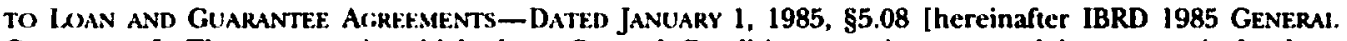
Conimions]. The manner in which these General Conditions are incorporated into a particular loan agreement is discussed in text at and notes 27-44 infra.

${ }^{15}$ In the relatively rich industrialized states, political support for continued participation in the MDBs turns in part on the fact that contracts under MDR-financed projects can usually be awarded onty to persons from member states of that MDB. For a statement of that general criterion, see THE. WORID BANk, GUIDELINESProcitikiment Uniser IBRD losans and IDA Creidits 7 (1985). The EBRD is an exception in this regard. It does not impose any country-eligibility criteria. See EUROPHAN BANK FOR RECONSTRUC:IION ANO DEvFloPMENT, Procurement Pollicies ant Rul.es 3 (1992, rev. Aug. 1994). For an example of how procurement eligibility bears on U.S. political support for MDB participation and funding, see U.S. DEPARTMENT OF TIIE TREASURY, The Mulmiaterat. Developmint Banks: Inckrfasing U.S. Exports and Crfating U.S. Jors 3 (1994).

16. The threats to refuse repayment of World Bank loans referred to in note 11 supra all seem to have been founded on political and economic grounds, rather than legal grounds. However, as pointed out in text at and notes 102-05 infra, unprecedented legal changes are now under way in many former Soviet republics. In that climate of radical legal change and uncertainty, it secms likely that as World Bank and other MDB loans in those countries increasingly come due for repayment, internal pressure for nonpayment might take the form of legal challenges. For a discussion of some other specific disputes that might arise if an MDB loan agreement were expressly or impliedly made subject to local law, see infra part $V$ of this article.

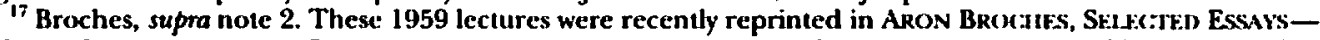

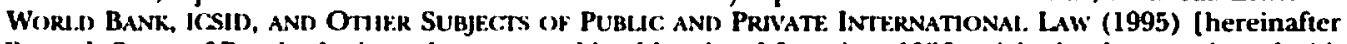
Essars]. Some of Broches's views also appeared in abbreviated form in a 1956 article that he coauthored with the World Bank's then-current General Counsel and another World Bank attorney. See Davidson Sommers, A. Broches \& Georges R. Delaume, Confliat Avoidance in Intemational Loans and Monetary Agreements, 21 LAW \& CONTRMP. Proks. 463, 476-78 (1956).

IN Broches's reasoning on this point is discussed in text at notes 55-57, 65-78 infra.

1" Broches's reasoning on this point is discussed in text at notes 58-61, 79-86 infra.
} 
Since the time of Broches's lectures, the law and operations of the MDBs have developed greatly. There are now more member states, ${ }^{20}$ more loans ${ }^{21}$ and more MDBs. Whereas 1959 saw only two such entities in operation-the International Bank for Reconstruction and Development ${ }^{22}$ and the International Finance Corporation ${ }^{23}$ - there are now no fewer than seven main international development finance institutions, ${ }^{24}$ headquartered on four continents and operating in a growing variety of political and economic circumstances. ${ }^{25}$

Of all these institutions, the one that departs most from the World Bank model is the most recently formed, the EBRD. The set of standard legal terms used in public sector loans extended by that institution reflects some important developments since the time of Broches's lectures in 1959. Specifically, one of the EBRD's standard terms relates directly to governing law: EBRD loan agreements, whether with member counuries or statc-owned enterprises, are explicitly made subject to public international law, which the EBRD standard terms define in a way that incorporates existing rules of international treaty and contract law and encourages the development of new customary rules. ${ }^{26}$

Part II of this article identifies and explains the main provisions of World Bank loan agreements that are relevant to the issue of governing law. Part III summarizes the traditional World Bank view-expressed by Broches and repeated by others-on the effects of those provisions, which remain substantially unchanged since 1959. Part IV explains the corresponding provisions of EBRD loan agreements, noting especially how and why they depart from those of the World Bank. Part $V$ then offers an assessment of the new EBRD approach and concludes that it represents an important step forward in the cvolution of MDB loan and guarantee agreements.

\section{The Structure and Relevant Provisions of World Bank Loan Agreements}

\section{The General Conditions and Projecl-Specific Loan Agreements}

The legal provisions governing a typical World Bank loan appear in at least two main documents: a set of General Conditions ${ }^{27}$ and a project-specific Loan Agreement ${ }^{28}$

\footnotetext{
${ }^{20}$ In 1959 the IBRD had 68 member states. Broches, supra note 2, at 304. As of June 1994, it had 177 member states. WB 1994 RFPORT, supra note 8, at 15.

"By 1959 the IBRD had made "more than two hundred loans . . . for a total equivalent of $\$ 4,500$ million" ( $\$ 4.5$ billion). Broches, supra note 2 , at 301 . By June 1994, the IBRD had made 3,660 loans for a total equivalent of about $\$ 250$ billion, and the IBRD and IDA combined had made 6,105 loans for a total equivalent of about $\$ 334$ billion. WB 1994 RfJort, supra note 8, at 233. See also infra note 94.

"re supra note 1. As explained there, the IBRD is one of the two entities that constitute the "World Bank." The other one, the IDA, did not exist in 1959.

"See supra note 1. IFC operations do not require government guarantees. See ARTICIss OF AGREEMENT OF TII: InItiknational. Finance. Cokjolkation, May 25, 1955, Art. 1(i), 7 UST 2197, 264 UNTS 117 (entered into force July 20, 1956).

${ }^{24}$ The IBRD, IDA, IFC, ADB, IDB, AFDB and EBRD. These are defined in text at and notes 1, 3-6 supra.

2"For a description of the political and economic "mandates" of the EBRD, see Head, Supranational Law, supra note 1 , at 636-41; SHILATA, supra note 6, at 441-42.

"*ri See text at notes 119, 131-37 infra.

s See IBRD 1985 GeNERA. CONIrmons, supra note 14. In addition to this set of General Conditions, there

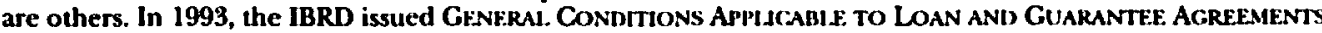
for Singll: Currfincy LoANs-DAtrin Ferruary 9, 1993 [hereinafter IBRD 1993 General. Conditions]. The IDA has its own separate set of General Conditions. See INTERnational. Deveiormint Association, GENE.RAI. Conditions Applicable to Deveioopmint Credit Agriliments-Dated January 1, 1985 [hereinafter IDA [985 Gentikat. Conditions].

in See WB OPER. MAN., supra note 12, at OP 7.01, 1\{3-6 (July 1994). Most World Bank loans are project loans rather than balance-of-payments loans. A World Bank project loan is designated for a particulas project that is described in detail in the Loan Agreement, reflecting decisions reached through negotiations between World Bank staff and government officials about the specific goods and services to be purchased with the loan proceeds. See id. The World Bank also engages in balance-of-payments support, called adjustrnent lending. This takes the form of loans conditioned on the making of certain economic and financial policy adjustments by the borrowing member country. See Head, Supranational Law, supra note 1, at 629; SultiATA, supra note 1, at $25-27,58-59$.
} 
between the World Bank and the borrower. If the borrower is a member state that will relend some or all of the loan proceeds to a state-owned enterprise, there might also be a Project Agreement between the World Bank and that state-owned enterprise. ${ }^{99}$ If the loan is made directly to a state-owned enterprise as borrower, there will also be a Guarantee Agreement between the World Bank and the member state providing the guarantee. ${ }^{\text {so }}$

At the center of these agreements are the General Conditions. The General Conditions "set forth certain terms and conditions generally applicable to loans made by the [World] Bank." 31 They apply whenever, and to the extent that, a particular Loan Agreement or Guarantee Agreement incorporates them by reference, ${ }^{32}$ which they typically do. ${ }^{33}$ If any inconsistency exists between the General Conditions and a Loan Agreement or Guarantee Agreement, the Agreement prevails. ${ }^{34}$ The General Conditions include numerous definitions ${ }^{35}$ and standard terms on commitment charges, ${ }^{36}$ repayment, ${ }^{37}$ withdrawal from the loan account, ${ }^{38}$ the currencies to be used for various purposes, ${ }^{59}$ loan suspension and cancellation, ${ }^{40}$ exchange of information, ${ }^{41}$ arbitration ${ }^{42}$ and effectiveness. ${ }^{48}$

With standard provisions thus established on a bankwide basis in the General Conditions, individual loan agreements can be shorter, focusing on the aspects of the transaction at issue. A typical loan agreement, for example, will specify the loan amount, the interest rate, detailed obligations of the borrower to carry out the project being financed, and any special conditions to be satisfied before loan disbursement can begin. ${ }^{4}$

\section{The Standard Provisions Most Relevant to Governing Law}

The standard provision bearing most directly on the issue of governing law for World Bank loan agreements appears in the first sentence of section 10.01 of the General Conditions now in force ${ }^{45}$ and is substantively unchanged from the provision appearing in the very first World Bank loan agreements of the late 1940 s. $^{46}$ The sentence reads as

See WB OPER. MAN, stupra note 12, at OP 7.01, 899-6 (July 1994).

5n See supra note 12 on the need for state guarantees. See also WB OPE.R. MAN., supra note 12, at OP 7.01. 97 (July 1994).

"IBRD 1985 General. Conimtions, supra note $14, \$ 1.01$

s. Id.

${ }^{33}$ Broches, supra note 2, at 305 . See also WB Orik. MAN., supra note 12, at OP 7.01, 13 (July 1994); Head, Conditionality, supra note 1 , at 17 .

\$4 IBRD 1985 GeNERAL. ConIIITIONS, supra note $14, \$ 1.02$.

${ }^{13}$ Id., \$2.01.

${ }^{36} \mathrm{Id}$., \$3.02.

"Id. \$3.04.

"Id., Art. V.

3" Id., Art. IV.

41" Jd., Art. V1.

${ }^{41} J d ., \$ \$ 9.01,9.02$.

4: $I$ d., $\$ 10.04$.

4" Id., $\$ \$ 12.01,12.02,12.03,12.04$.

"4 Se WB Oper. MAN., supra note 12, at OP 7.01, 193-6 (July 1994). For an example of a World Bank loan agreement including these and other details, see the Loan Agreement for the Shanghai Environment Project, between the People's Republic of China and the International Bank for Reconstruction and Development, Loan No. 3711 CHA (June 2, 1994). This and other World Bank loan agreements are available to the public, for a fee, lurough the World Bank Public Information Center (1818 H Street, N.W., Washington, DC 20433; fax (202) 477-6391).

45 See IBRD 1985 Generu. Conmitions, supra note 14, \$10.01; IBRD 1993 Genferni. Conimtions, supra note 27. \$10.01; IDA 1985 GeNkRAI. Conditions, supra note $27, \$ 10.01$. All portions of Article $X$ of each of these sets of General Conditions are identical in all relevant respects, and henceforth this article refers only to the IBRD 1985 General Conditions.

th See International. Bank for Reconstructikn and Devfi.opment, Genfral. Contottions applicable: TO LOAN AND GUARANTkE. A(irkements-Datkis MARCII 15, 1974, \$10.01 [hereinafter IBRD 1974 GENk:RAt. CONIDTIONS]; INTERNATIONAI. BANK FOR RECONSTKUICTION AND DEvliloIPMENT, LOAN RFigulations No. 3DATEI) JUNE 15, 1956, \$7.01 (applying to loans made to member states) [hereinafter WB 1956 LoAN Reguiations]; International. Bank for Riconstikuction and Development, loan Rrgulations No. 4-DATKD JUNE 15, 1956, $\$ 7.01$ (applying to Joans guaranteed by member states). Broches quotes the first 
follows: "The rights and obligations of the Bank, the Borrower and the Guarantor under the Loan Agreement and the Guarantee Agreement shall be valid and enforceable in accordance with their terms notwithstanding the law of any State or political subdivision thereof to the contrary." ${ }^{47}$

This provision is as close as the General Conditions come to specifying a governing law. It obviously is not a typical governing law provision, ${ }^{48}$ as it does not affirmatively designate any particular legal system (for example, "the laws of New York" or "English law"). Instead, it is narrow and negative in character: domestic law (that is, the law "of any State or political subdivision thereof") will not apply-will be, in effect, overridden by the terms of the agreement-in case of a conflict between those terms and that domestic law. The implications of this formulation are discussed below in part III.

A second provision in the World Bank's General Conditions also throws some light on the question of governing law. Section 10.04 is addressed to dispute settlement. It provides that any controversy between the parties to the Loan Agreement or the Guarantec Agreement that has not been settled by agreement of the parties "shall be submitted to arbitration by an Arbitral Tribunal as hereinafter provided." It then sets forth the procedures by which the arbitration will be conducted: within specified time periods triggered by one party's notification of a desire to pursue arbitration, a three-person arbitral tribunal will be constituted to hear the dispute, ${ }^{50}$ in accordance with procedures it establishes largely on its own, ${ }^{51}$ and to render a decision that will be enforceable in national courts. ${ }^{52}$ Despite these detailed provisions-section 10.04 is longer than any other section in the General Conditions-section 10.04 does not include a provision on the governing law to be applied by the arbitral tribunal.

These are the main provisions in the World Bank's General Conditions that relate to the issue of governing law for World Bank loan and guarantee agreements. ${ }^{53}$ We now turn to the views expressed by Broches on that subject in 1959.

sentence of $\$ 7.01$ of Loan Regulations No. 3 and then states that "[t]his formula was drafted in 1947, when the Bank was about to undertake its first loan transaction." Broches, supra note 2, at 344. Accord, Hugh N. Scott, The Enforceability of Loan Agreements Between the World Bank and Its Member Countries, 13 AM. U. L. Rev. 185, 190 (1964).

"IBRD 1985 GenERAI. ConiornoNs, supra note $14, \$ 10.01$. The second sentence of that provision states that none of the partics may claim "that any provision of these General Conditions or of the Loan Agreement or the Guarantee Agreement is invalid or unenforceable because of any provision of the Articles of Agreement of the Bank." For an analysis of the 1956 version of this sentence (which was somewhat broader in coverage because it included "or for any other reason" at the end), see Broches, supra note 2, at 362-63, 368-69. For a comparison with the corresponding provision in the EBRD's standard terms, see infra text at note 111.

${ }^{44}$ For a sample of a governing law provision, see Viol P. NANDA, Forum Selection and Choice of Law Clauses in Transnational Contracts, in 1 TIIE I AW of Transnational. Business Transactions, App. 5A (loose-leaf, July 1995) (reading in pertinent part as follows: "This contract . . . shall be governed by and enforced in accordance with the laws of . . .."). On governing law provisions and the various purposes to be served by them in international contracts, sec FresiffiEl.tus GuIJF, supra note 11, at 31-40. For such a discussion in the context of international project loan agreements involving private sector lenders, see generally Kimmo Mettälã, Governing-Law Clauses of Loan Agreements in International Project Financing, 20 INI"L LAw. 219 (1986).

1" IBRD 1985 General. ConDrTIONS, supra note $14, \$ 10.04$ (a).

5n The instituting party is to notify the responding party of the claim being made, the relief being sought, and the name of the arbitrator it has appointed. Within 30 days after such notification, the responding party is to name the arbitrator it has appointed. Id., $\$ 10.04(\mathrm{~d})$. The parties are then expected to agree on a third arbitrator (the "Umpire"), but if they cannot agree within 60 days after the instituting party's notification, the Umpire will be appointed by the President of the International Court of Justice or, failing that, by the Secretary-General of the United Nations. Id., \$10.04(c), (e).

st The arbitral tribunal "shall decide all questions relating to its competence and shall, . . except as the parties shall otherwise agree, determine its procedure," subject to a few other procedural matters covered in $\$ 10.04$. Id., $\$ 10.04(\mathrm{~g})$.

52 Id., $\$ 10.04(\mathrm{k})$. An exception exists in the case of an arbitral award against a member state: the state's sovereign immunity, to the extent it is claimed, is not waived by operation of $\$ 10.04$. Id. See also Broches, supra note 12 , at 259 .

"A third set of provisions in the World Bank's General Conditions bear on the legal status of World Bank loan agreements upon signature-that is, on the legal significance of the act of signing them. Section 12.01 of the General Conditions provides that a Loan Agreement and Guarantee Agreement "shall not become 


\section{The legal. Character of World Bank loan Agreements}

\section{The Traditional View in a Nutshell}

The traditional view of the legal character of World Bank loan agreements, as articulated by Broches in 1959, may be summarized thus:

(1) Agreements with members. Every loan agreement between the World Bank and a member state, and every guarantee agreement (which is by definition with a member state ${ }^{54}$ ), is an international agreement "governed by international law," as both parties to such agreements have international legal personality. These agreements are ". 'treaties' in the broad sense of the term, as a matter of international law, $"$ ati and are registered with the United Nations as such. ${ }^{57}$

(2) Agreements with nonmembers. A loan agreement between the World Bank and a nonstate borrower (for example, a state-owned enterprise) "is certainly not an international agreement governed by international law,"5s since the nonstate party does not have international legal personality. Such an agreement does, however, "partake [ ] of the international character" 59 of the dealings between the World Bank and the member state, which justifies "insulating it from the effect of municipal law." ${ }^{\text {(6) }}$ Reflecting these attributes, such agreements are not registered separately with the United Nations but are provided instead "as an annex to the related guarantec agreement." ${ }^{\prime 61}$

Broches posited these views in 1959, at about the beginning of his tenure as General Counsel of the World Bank..$^{62}$ They had apparently not changed in 1980, when he wrote a brief overview of the World Bank after completing two decades in that position. ${ }^{63}$ In expressing these views, Broches set forth a number of key propositions about the World Bank, its legal character, and the legal basis for its relations with both members and nonmembers. ${ }^{64}$ Several of those warrant attention.

effective until evidence satisfactory to the Bank shall have been furnished to the Bank . . that the execution and delivery of [those Agreements] on behalf of the Borrower and the Guarantor have been duly authorized or ratified by all necessary governmental and corporate action." IBRD 1985 GENERAL. CoNDrTIONS, supra note $14, \$ 12.01$ (a). This provision suggests that the Loan Agreement and Guarantee Agreement are not legally binding and effective immediately upon signature, a suggestion that is bolstered by $\$ 12.09$. It provides that the Loan Agreement and Guarantee Agreement "shall enter into effect on the date upon which the Bank dispatches to the Borrower and to the Guarantor notice of its acceptance of the evidence required by Section 12.01." Id., \$12.03(a). In explaining these provisions, Broches has pointed out that "it is clearly not contemplated that the loan agreement [or the guarantee agreement] will come into force upon signature." Broches. supra note 2, at 392. Between the time of signing and the time of effectiveness, the borrower has the "option" to proceed with the loan or not, id. at 394 , and "is under no obligation to bring the agreement into force." Id. at 397.

${ }^{54}$ See supra note 12 on the need for state guarantees.

5 Broches, supra note 2, at 353.

.6. Id. at 405.

${ }^{57}$ Id. at 353 .

sw Id. at 351

sy Id. at 352

in Id.

iil Id. at 354. As Broches noted, id. at 353, Article 102 of the UN Charter provides for the registration of "every treaty and every international agreement." World Bank loan agreements and guarantee agreements with members are registered with the United Nations pursuant to that provision. Id.

62 For information on Broches's career, see Brociles, EssaYs, supra note 17, at xiii.

his See Broches, supra note 12, at 254, 258-59. Moreover, as noted in note 17 supra, Broches's 1959 lectures were reprinted in 1995 without any indication that his views on the legal character of World Bank loan agreements had changed over the intervening period.

int In expressing views about World Bank loan agreements and these underlying legal issues, Broches was largely reflecting the views of the World Bank Legal Department, based on legal provisions that were developed before he became General Counsel. In particular, his 1959 Hague Academy lectures were intended less as an exposition of his own personal views on these matters than as an explanation of World Bank practice, and its legal moorings, as developed institutionally. Telephone conversation between the author and Aron Broches (June 25, 1995). 


\section{Legal Foundations of the Traditional View}

First, Broches took the position, supported by extensive argument, that the World Bank is "a subject of international law, that is to say it possesses international personality. "tis Like many other international organizations, he said, the World Bank has the legal capacity to enter into treaties. ${ }^{66}$ Not all international agreements between subjects of international law (for example, a state and an international organization) are treaties, since those subjects "may, if they choose, subject their agreements to municipal law,"67 instead of international law. ${ }^{68}$ Loan agreements entered into by the World Bank and its member states, however, are not of a type commonly made subject to municipal law; ${ }^{69}$ instead, such agreements contain numerous provisions that "taken as a whole implicilly negative any inference that the agreements belong to the sphere of municipal rather than international law."

Broches next turned to the then-current equivalent of section 10.01 of the General Conditions quoted above, ${ }^{71}$ in which the rights and obligations created in World Bank loan agreements were made "valid and enforceable in accordance with their terms notwithstanding the law of any state, or political subdivision thereof, to the contrary." 72 He acknowledged that this formulation was not as straightforward as stating that "the rights . . . of the parties shall be governed by international law, ${ }^{, 73}$ but he explained that this "somewhat unusual and negative formulation" "74 reflected the uncertainty in 1947 (when the language was first drafted) ${ }^{75}$ over the legal nature of international organizations and their legal capacity. ${ }^{76}$ Nonetheless, Broches asserted, the effect of the provision "is not merely to de-nationalize [World Bank loan] agrecments [with member states $^{77}$ ], but to subject them in all respects to international law."

Broches then turned his attention to loan agreements between the World Bank and entities other than states ${ }^{79}$ - for example, state-owned enterprises. Reflecting the view then held that only international persons contracting among themselves were capable of having public international law govern their agreements, Broches reasoned that a loan agreement between the World Bank and an entity other than a state "is certainly not an international agreement governed by international law," as it is "an agreement between a subject of international law and an entity which does not possess that qual-

$\therefore$ Broches, supra note 2, at 328 . See also id. at 326.

twid. at $329,338$.

it Id. at 339.

in This view was expressed later in the 1969 Vienna Convention on the Law of Treaties, which included in its definition of a treaty the criterion that it is to be "governed by international law," suggesting that some international agreetnents between subjects of international law may nonetheless be governed by municipal law. See Vienna Convention on the Law of Treaties, May 23, 1969, Art. 2(1)(a), 1155 UNTS 331, 8 ILM 679 (1969) (entered into force Jan. 27, 1980) [hereinafter 1969 Vienna Convention].

Broches, supra note 2, at 343.

inl Id. at 344 .

"See supra text at note 47 .

72 Broches, supra note 2, at 344 (quoting WB 1956 LOAN RkcillATIONs, supm note 46, 57.01).

7 Id.

$\therefore$ Id. al 345.

73 See supra note 46.

76 Broches, supra note 2, at 344. See also Scott, supra note 46 , at 190.

7 As noted above, Broches was at this point in his lectures referring to $\$ 7.01$ of the Loan Regulations applicable to loan agreements with member states. See supra notes $46,72$.

${ }^{7 x}$ Broches, supra note 2, at 345. Specifically, as another World Bank attorney has explained, "[t]he interpretation of the agreement will depend on international law, the rights of the parties will be given effect by international law and the remedies available to enforce these rights will be those available under international law:" Scott, supra note 46, at 190. The applicability of international law is pertinent to the arbitration provisions in the General Conditions. Although those provisions "contain no standards or suggestions to guide the arbitrators in making their decision," it may be assumed that "the arbitrators would, like the International Court of Justice, look to international custom and the general principles of law recognized by civilized nations." Jd. at 191-92.

"Broches, supra note 2, at 351. 
ity. ${ }^{" * 0}$ Broches acknowledged that it might not be immediately evident how the provisions of such an agreement could be superior to conflicting provisions of municipal law. ${ }^{81} \mathrm{He}$ explained that the kind of guarantee required by the World Bank when making a loan to a nonmember was unusual, in that the guarantor's obligation was "as a primary obligor, and not as surety merely." " Therefore, the loan agreement with the nonmember was to be seen in fact as "only one element . . . in the dealings on the international level between the [World] Bank and its member, and partakes of the international character of these dealings." ${ }^{\prime s}$

It appears that the World Bank approach, as explained by Broches, leaves the World Bank loan agreement with a nonmember in a legal no-man's-land, since it is not, strictly speaking, governed either by international law ${ }^{84}$ or by municipal law. ${ }^{85}$ In the latter respect - insulation of such an agreement from municipal law-Broches explained that, "while the borrower could not contract itself out of the application of municipal law, the [World] Bank and the guaranteeing member may do so in respect not only of their own relationship but also . . . of that between the [World] Bank and the borrower."

\section{A New Approach - The EBRD's Standard Terms and Conditions}

\section{Practical Concerns in a New Setting}

The issue of governing law for World Bank loan agreements apparently has never been formally addressed through arbitration or in attempted litigation. ${ }^{87}$ Indeed, since Broches's 1959 lectures the subject has apparently received only slight attention, mainly in the $1960 \mathrm{~s}^{88}$ and early $1980 \mathrm{~s}^{89}{ }^{89}$ in 1982 one commentator reasoned that, although it might be advisable for the World Bank to reformulate section 10.01 to specify interna-

"ur Id.

"Id. Id.

kz Id. at 352

"Id.

Mt Id. at 344 .

xs Id. at 352.

*h Id. Broches also pointed out that it made sense for the pertinent provision in Loan Regulations No. 3 and Loan Regulations No. 4, applying to loan agreements with members and nonmembers, respectively, to be drafted identically (rather than differently to reflect the different types of borrowers in the two cases) because in many circumstances where the World Bank made a loan to a nonmember, "the transaction could as well take the form of a loan to the member government," id., and that the World Bank's "legal position should be essentially the same in result, regardless of the technique adopted." $l d$. at 353.

"See Mark Augenblick \&e Delissa A. Ridgway, Dispute Resolution in World Financial Institutions, 10 J. INrt. ARR. 73, 82 (1993) (noting that "there has never been an actual arbitration between any major multilateral development bank and a borrower"). See also Broches, supra note 12, at 259 (noting that as of 1980, the World Bank arbitration provisions "ha[d] never been invoked").

${ }^{\mathrm{NK}}$ At a conference held in $\mathbf{1 9 6 8}$ under the auspices of the American Society of International Law, several legal officers from MDBs and similar entities offered views on certain legal aspects of loan agreements entered

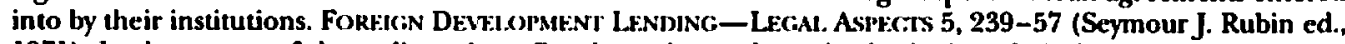
1971). In the course of those discussions, Broches reiterated a point he had made in his 1959 lectures: that a World Bank loan agreement typically does not come into force upon signature. Id. at 248. As pointed out in note 53 supra, provisions on this issue appear in $\$ 12.01$ of the World Bank's General Conditions. For a related discussion about effectiveness of World Bank loan agreements, see Grokcies R. DE1AUME, I.ficiAl

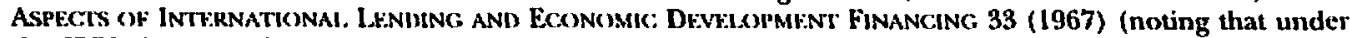
the IBRD loan regulations, a loan agreement normally becomes "effective at some time after the date of signature, since conditions of effectiveness" take time to be fulfilled). For other scholarship appearing in the 1960s about legal aspects of World Bank loan agreements, see generally Scott, supra note 46; and Cecil J. Olmstead, Pubtic Econonic Development Loan Agmements; Choice of Law and Remedy, 48 CAl.. L. REv. 424 (1960).

"Ne Ge Georges R. Delaume, Issues of Applicable Law in the Context of the World Bank's Operations [hereinafter applicable [aw], in 2 Tut. Transnational. LaW of Intrinationat. Commercial. Transactions 317 (Norbert Horn \& Clive M. Schmitthoff eds., 1982) [herejnafter Commercial. Transactions]. Although other references to the traditional World Bank view as expressed by Broches have appeared occasionally, they generally have offered no criticism or analysis of it. See, e.g., 2 PIII.JP' Woon, LaW and Practice: of Internationat. Finanit: $\$ 1.07$ [2][b] (loose-leaf, Apr. 1983); 1 Georcess R. Dlilaume, Transnational. Contrac:ts-Applicable: 1alw' ANis Sritrtesuent of Disputes \$1.14 (loose-leaf, Dec. 1989) [hereinafter ConTRACTs]. 
tional law as the governing law, there was no urgency to making such a reformulation because "not a single case has arisen in which recourse to arbitration proved necessary." 90 That being the case, it might seem unnecessary to open the subject now.

However, as noted above, the institutional landscape has changed dramatically since $1959,{ }^{91}$ especially because of the emergence of the regional MDBs-the ADB, the IDB, the AFDB and the EBRD. ${ }^{92}$ The first three of these largely adopted the World Bank's General Conditions for purposes of their own lending operations. ${ }^{13}$ As a result, the overall volume of lending undertaken by all MDBs under the legal regime established by the World Bank, as described in parts II and III above, is more than a hundred times greater now than it was in $1959 .^{9-1}$ On the basis of this fact alone, it seems appropriate to review the governing law and enforceability of the loan agreements under which these operations are conducted.

Beyond that, however, lies another important development. The newest of the MDBs, the EBRD, departs in several respects from the mold on which its predecessors were patterned. ${ }^{95}$ It faces some different challenges that make the issue of governing law important enough to warrant a fresh examination.

For example, the EBRD is the first MDB designed to facilitate directly the privatization of state-owned enterprises. As part of its overall mandate of "fostering the transition of Central and Eastern European countries towards open market-oriented economies,"

"Delaume, Applicable Law, supra note 89, at 323. Delaume's reasoning, in pertinent part, was as follows:

The practice of many international organisations reveals . . . that contracts between them and domestic law persons are no longer necessarily rooted in municipal law... [but can be governed by] international law.

[Therefore] the question arises whether it might be advisable for the [World] Bank to take a second look at Section 10.01 and to clarify its meaning. Admittedly the negative formulation of that old provision is awkward. Admittedly also, to give, as Mr. Broches did, a dual meaning to a single provision which should govern both the relationship between the Bank and one of its members and that between the Bank and a borrower other than a member is an invitation to criticism. Rather than approaching the basic issue in this timid fashion, the Bank might be better advised to . . . provide, firmly and in a positive way, that its loan/guarantee agreements, whether concluded with a member country or not, are always subject to international law . . . . Such a reformulation of Section 10.01 would be in line with modern trends of legal thinking and would dispel the ambiguitics of Section 10.01 in its present form.

Id. Delaume went on to say, however, that redrafting \$10.01 was not likely to "entail dramatic practical consequences" because it "has never been put to the test of international adjudication." He therefore saw no "urgency" to redraft the section. Id. at 323-24.

${ }^{91}$ See text at and notes 20-25 supra.

"ri: See supra notes $3,4,5$ and 6 .

97 See, e.g., Aslan Devpilomment Bank, Ordinary Operations loman Rfgulations-Dated 1 jui.y 1986 [hereinafter ADB 1986 LOAN RKoulATIONS]. Although presented in a slightly different order, the ADB's standard terms are virtually identical in substance to the World Bank's standard terms, including in particular those on enforceability and arbitration. Compare IBRD 1985 GENFrRA. CONDITIONs, supra note $14, \$ \$ 10.01$, 10.04 with ADB 1986 LOAN RlicutsTIONS, supra, $\$ \$ 10.01,10.04$, respectively. The same similarity is found with the standard terms used by the AFDB. Compare IBRD 1985 GENFrRA. ConIIITIONS, supra, $\$ \$ 10.01,10.04$ with

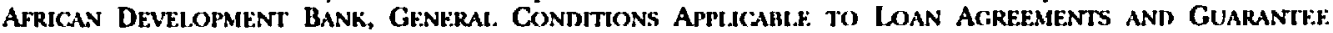
Agremants \$\$13.01, 13.04 (Nov. 23, 1989) [hereinafter AFDB 1989 Gint:Rl. Conditions]. The standard terms used by the Inter-American Development Bank are silent on the governing law (they do not even include an exclusion-of-local-law provision like the one in \$10.01 of the World Bank's General Conditions), but they do contain arbitration provisions closely similar to those of $\$ 10.04$ of the World Bank's General Conditions. See Inter-aMerican Deivelopmint Bank, General. Condtrions (Ordinary CaptTal), \$\$9.01-9.06 (1994) [hereinafter IDB 1994 Gentral. Condrtions].

'4 supra note 21. As noted there, cumulative lending by the World Bank in 1959 totaled about $\$ 4.5$ billion. By 1994, cumulative public sector lending by all the MDBs except the EBRD (which in fact also largely followed World Bank practice on governing law in its public sector loan agreements until 1994) had exceeded

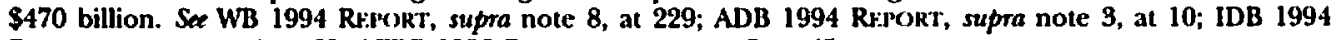
RE:PORT, supra note 4, at 39; AFDB 1993 REPOKr, supra note 5, at 45.

9.5 On why the EBRD can be considered a "third generation international financial institution," see Head, Supranational Law, supra note 1, at 641-44.

W EBRD Cinarter, supro note 6, Art. 2(1). See also id., Art. 1 (same), and Art. 11(3) (requiring that loans to the state sector not exceed $40 \%$ of the EBRD's total loans, guarantees, and equity investments). On the EBRD's "economic mandate," see Head, Supranational Law, supra note 1, at 640-41 and sources cited there. 
the EBRD is expected, according to its charter, to "invest[ ] in the equity capital of any state-owned enterprise to facilitate its transition to private ownership and control." Thus, the distinction between private sector financing of the type conducted by the International Finance Corporation ${ }^{48}$ and public sector lending of the type conducted by the World Bank" becomes fuzzy in the case of the EBRD. Both types of financing take place, in substantial amounts, in the same lending institution (the EBRD), conceivably with the same borrower over time. ${ }^{101}$ Nonetheless, because private sector operations do differ in important respects from public sector operations, ${ }^{101}$ issues of governing law and validity for purposes of public sector transactions would best be clearly articulated.

Moreover, the EBRD is working in a political environment that is very different from those faced by other MDBs on their establishment. Most of the EBRD's countries of operations are undergoing wrenching political transformations from subordinate political entities within the Communist world to independent sovereign states experimenting for the first time in decades (or perhaps ever) with democratic institutions. ${ }^{192}$ Indeed, one of the purposes of the EBRD is to facilitate that very change, by promoting "the principles of multiparty democracy [and] pluralism." "1113 Largely because of these political transformations, the legal foundations in the EBRD's countries of operations are typically shaky, with radical changes in the legal systems and constitutions appearing as the norm rather than the exception. ${ }^{104}$ In such a setting, it makes sense both from the perspective of the EBRD and from that of its borrowers to be as clear as possible about the legal nature and enforceability of EBRD loan agreements. ${ }^{10.5}$

"97 EBRD CILARTY., supra note 6, Art. 11(1)(ii)(b). Various other types of investments are also authorized. See generally id., Art. 1.

See supre notes $1,23$.

"y See supra notes $1,12$.

${ }^{1141}$ As further evidence of the EBRD's aim of making its public sector loans subject, as much as possible, to the rigors of private sector terms, the explanatory notes to Article 14 of the EBRD Charter (which provides that the EBRD "may" require a state guarantee in lending to a state-owned enterprise) emphasize the importance of weaning state-owned enterprises away from government dependence. See Chainnan's Report on the Agreenent Establishing the Europrean Bank for Reconstrurtion and Development, reprinted in Siutlata, supra note 6, at 166, 174 (pointing out "that a state-owned enterprise would be more likely to respond quickly to market forces, and to make the transition to market-oriented economies, if that enterprise could not rely on a government guarantee to discharge its responsibilities under a Bank loan"). See also Hurlock, suppa note 12, at 380.

III' The differences between private sector and public sector operations in the EBRD appear in various forms. For example, the EBRD's procurement guidelines distinguish clearly between those applicable to public sector operations and those applicable to private sector operations. See EUROPEAN BANK FOR RECONSTRUCTION AND Devilopment, Procturfament Pol.jcies and Rul.es 8, 21 (1993); European Bank for Reconstruction and Developmint, FInANCINC: wTru THE. EBRD 12 (1994). The same distinction appears in the EBRD's disburse-

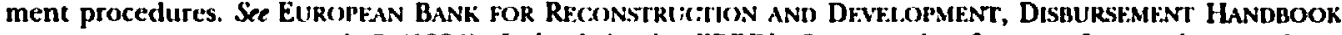
FOR PUBt.IC: SFC.TOR I.OANS 4-5 (1994). Indeed, in the E.BRD's first couple of years of operations, a sharp organizational clivision between public sector and private sector operations existed. See EUROPFAN Bank fOR

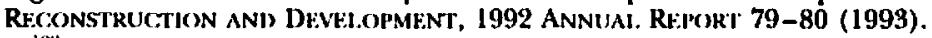

${ }^{102}$ When the EBRD's charter was drafted, there were to be 8 countries of operations (that is, member countries eligible to borrow); by early 1993 (less than two years after it commenced operations), the breakup of the Soviet Union and Yugoslavia had resulted in an increase from those 8 to 25 countries of operation. See Head, Supranational Law, supra note 1, at 645-46.

"I"s EBRD CILATTrR, supra note 6, Art. 1. For a description of the EBRD's "political mandate" and how it distinguishes that institution from the other MDBs, see Head, Supranational Law, supra note 1, at 636-38.

1"4 For a partial survey of legal and constitutional changes in the countries of Central and Eastern Europe and central Asia, sec A.B.A., C.ELL) UPDATE, Fall 1995, at 3-32 (reporting on recent work of the ABA's Central and East European law Initiative in legal and constitutional reform in 20 states in Eastern and Central Europe and central Asia). For assessments of the constitutional changes in some of those countries, see Eric Stein, Intemationat Law in Internal Law: Toward Intemationalization of Central-Eastem European Constitutions?, 88 AJlL 427 (1994) (focusing on the Czech Republic and the Slovak Republic); Gennady M. Danilenko, The New Russian Constitution and International Law, id. at 451 (focusing on Russia).

"t". Another legal issue- - jurisdiction - also points in favor of carefully setting forth the legal nature of EBRD loan agreements. The E.BRD Charter, like the IBRD Charter, provides that legal actions may be brought against the institution, by parties other than member countries, "in a court of competent jurisdiction in the territory of a country in which the [EBRD] has an office." EBRD CuARTrR, supra note 6, Art. 46; see also IBRD CiartER, supra note 12, Art. VII, \$3. The EBRD has offices in more than a dozen of its countries of operation. See EBRD 1994 REf(oRT, supra note 6, back cover. If, in suing the EBRD in a local court, an individual or 
Given these circumstances, it is not surprising that the EBRD has taken a new approach to the formulation of certain standard terms and conditions for its public-sector lending operations. Unlike the other regional MDBs, whose standard loan terms are modeled directly on the World Bank's General Conditions, ${ }^{\prime M j}$ the EBRD's Standard Terms and Conditions depart from the World Bank's approach in several ways. The following paragraphs discuss the key provisions of those Standard Terms and Conditions that bear on the subject of this article-governing law.

\section{EBRD Standard Provisions on Enforceability and Dispute Resolution}

The EBRD first established a set of Standard Terms and Conditions (STCs) for public sector loans in March $1994,{ }^{107}$ after about three years of operations. ${ }^{108}$ Minor revisions were made to the STCs in September 1994. ${ }^{109}$

The provisions on enforceability and dispute resolution appear in sections 8.01 and 8.04, respectively, of the STCs. The first of these is closely similar in content to the corresponding provision in the World Bank's General Conditions ${ }^{110}$ and reads as follows:

The rights and obligations of the parties to the Loan Agreement and the Guarantee Agreement shall be valid and enforceable in accordance with their terms notwithstanding any local law to the contrary. No party to either such agreement shall be entitled under any circumstances to assert any claim that any provision of either such agreement is invalid or unenforceable for any reason. ${ }^{\prime \prime \prime}$

On the subject of dispute resolution, however, the STCs depart rather dramatically from the World Bank model. As explained above, the World Bank's General Conditions attempt to provide in detail for every eventuality in the establishment and operation of an arbitral tribunal if a dispute should arise that cannot be settled by agreement of the parties; but the General Conditions do not specify a governing law to be applied by such a tribunal. ${ }^{112}$

group in one of those countries of operations makes reference to an EBRD loan agreement, the court would need to understand the nature of that agreement.

ING See supra note 93.

107 See genetally Europian Bank for Reconstruction and Devilopmpint, Stanidard TERMs anid Conimtions (Mar. 1994) [hereinafter EBRD MARch 1994 STCs]. Section 1.0] of the STCs provides that "[a]ny loan agreement or guarantee agreement of the Bank for an operation made to, or guaranteed by, a member of the Bank may provide that the parties to that agreement accept the provisions of these Standard Terms and Conditions." Id. \$1.01. As other provisions in the STCs confirm, this opening section makes the STCs generally applicable (subject to modification in particular transactions) to every agreement with a party having a financial obligation to the EBRD under a public sector loan; that is, applicable (1) to the loan agreement where the loan is made to the member state, and (2) to both the loan agreement and the guarantee agreement where the loan is marle to an entity other than the member state (for example, a state-owned enterprise) and is guaranteed by the member state. Sec, e.g., id. $\$ \$ 4.01,6.01$ (a) (ii), 7.01(a), 7.04, 8.01, 8.04(a), 9.01-9.05, and 10.03 (either imposing obligations simultaneously on both the borrower and the guarantor, as in \$8.01, quoted in text at note 111 infra, or referring to both the loan agreement and the guarantee agreement as being instruments governed by the STCs). In this respect, \$1.01 of the EBRD's STCs uses the same general formulation as those in the corresponding sets of standard terms of most of the other MDBs. Compare id. \$1.01 with IBRD 1985 GENERAL. CONDITIONS, supra note 14, \$1.01, ADB 1986 LOAN RFCUIATIONS, supra note 93, \$1.02, and AFDB 1989 GENE:RAl. CONDITIONS, supro note 93, \$1.01.

IEx The EBRD approved its first loan in June 1991. See EuRoplan Bank fok Rrconstruction and DtivejopMENT, 1991 ANNUAl. RFirort 20 (1992).

Iry See genetally Europran Bank for Reconstruction ani) Diveiospment, Standard Terms anid CondiTIONS (Sept. 1994) [hereinafter EBRD SFPTEMBr:R 1994 STCs]. The changes included, inter alia, a minor revision to the method of calculating the commitment charge. Compare id. with EBRD MARCH 1994 STCs, supra note 107.

II" See IBRD 1985 GenfRA. Connitions, supte note $14, \$ 10.01$.

'11 EBRD SFPTriabre 1994 STCS, supra note 109, \$8.01. The second sentence of the STC provision is somewhat broader in coverage than the second sentence of the corresponding World Bank provision, quoted in note 47 supra.

${ }^{112}$ See supra text at notes $49-52$. 
Section 8.04 of the EBRD's STCs differs from those World Bank provisions in three ways. First, section 8.04(a) claborates on the requirement that the parties initially "endeavour to setule amicably any dispute or controversy between them" before proceeding to arbitration. ${ }^{.13}$ Second, section 8.04 (b) provides that, if arbitration is necessary, it shall be carried out "in accordance with the UNCITRAL Arbitration Rules." 114 Reference to the UNCITRAL. Rules naturally was not possible when the World Bank provisions were being formulated, because these rules did not exist until 1976. Third, section 8.04(b) then enumerates certain specific terms pertinent to the application of the UNCITRAL Rules, such as the number of arbitrators (threc), ${ }^{115}$ the place of arbitration (The Hague), ${ }^{116}$ the language to be used in the arbitral proceedings (English), ${ }^{117}$ and the law to be applied by the arbitral tribunal. ${ }^{118}$

It is especially on this last point - the law to be applied-that the dispute resolution provision of the STCs departs radically from the corresponding provision in the World Bank's General Conditions. Section 8.04(b) (v) prescribes "public international law" as the law to be applied. That clause reads as follows:

(v) The law to be applied by the arbitral tribunal shall be public international law, the sources of which shall be taken for these purposes to include:

(A) any relevant treaty obligations that are binding reciprocally on the parties;

(B) the provisions of any international conventions and treaties (whether or not binding directly as such on the parties) generally recognised as having codified or ripened into binding rules of customary law applicable to states and international financial institutions, as appropriate;

(C) other forms of international custom, including the practice of states and international financial institutions of such generality, consistency and duration as to create legal obligations; and

(D) applicable general principles of law. ${ }^{119}$

This enumeration of the sources of public international law for the purposes of arbitration under an EBRD loan agreement roughly parallels the enumeration of "sources" in Article 38(1) of the Statute of the International Court of Justice, ${ }^{120}$ which provides that the Court is to apply treaties, custom and general principles in deciding

"' EBRD SEPTEMBER 1994 STCs, supra note $109, \$ 8.04(a)$, which reads as follows:

The parties to the Loan Agreement and the Guarantee Agreement shall endeavour to settle amicably any dispute or controversy between them arising out of such agreements or in connection therewith. To this end, at the initiative of any party to either such agreement, the other party or parties shall meet promptly with the initiating party to discuss the dispute or controversy and, if requested by the initiating party in writing, shall reply in writing to any written submission made by the initiating party concerning the dispute or controversy.

In contrast, the World Bank provisions make only passing reference to the possibility that a dispute might be "settled by agreement of the partics." See IBRD 1985 Ginreral. Condrnons, supra note $14, \$ 10.04$ (a).

114 For the UNCITRAl. Arbitration Rules, Apr. 28, 1976, see 2 BASIC: DocumkinTs, supra note 12, at 1019, and 15 ILM 701 (1976). For an overview of the rules and their status, see 2 BAsic: DocumenTs, supra, at $1015-18$. ${ }^{115}$ EBRD SEPTEMBE:R 1994 STCS, supra note $109, \$ 8.04$ (b) (i).

IIF Id., \$8.04(b) (iii). The specification of a place of arbitration is important for (among other things) the enforcement of an arbitral award. For example, the New York Convention requires each contracting state to enforce arbitral awards made in the territory of other contracting states. United Nations Convention on the Recognition and Enforcement of Foreign Arbitral Awards, June 10, 1958, Arts. I, 111, 21 UST 2517, 330 UNTS 3 (entered into force June 7, 1959).

${ }^{117}$ EBRD SeITrEmiki 1994 STCs, supra note 109, \$8.04(b) (iv).

${ }^{11 x} / d ., \$ 8.04(\mathrm{~b})(v)$.

$119 \mathrm{Jd}$.

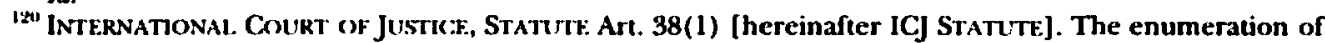
"sources" of international law in Article 38 can be traced back to at least about 1919, as the language of that article is virtually identical to the wording of Article 38 of the governing Statute of the IC]'s predecessor, the Pemmanent Court of International Justice, mprinted in ANtonio S. DF. Bustamante. THe Worl.s Court 353 (Elizabeth F. Read trans., 1925). See also IAN Bkowni.1E, Principles of Puil.tc: Intr.knationat. Law 71416 (4th ed. 1990). 
disputes submitted to it. ${ }^{121}$ However, the language of section 8.04 of the STCs reflects the fact that one of the parties to arbitration thereunder will be an "international financial institution" international law. ${ }^{123}$

This initiative taken by the EBRD in its dispute resolution provisions-specifying an applicable law rather than remaining silent (or relying on inference) as in the World Bank's General Conditions-represents a significane step forward in the evolution of the governing law for MDB loan agreements. ${ }^{124}$ As explained above, the traditional view of World Bank loan agreements was (1) that if between the World Bank and a state, they were governed by international law as treaties, and (2) that if between the World Bank and an entity other than a state, they were not (and could not be) governed by international law but could be insulated from local law (and were so insulated by operation of the General Conditions) on grounds that they "partake[ ] of the international character of [the] dealings" between the World Bank and the relevant member state. ${ }^{125}$ In contrast, the EBRD's STCs have swept all such agreements-with states and nonstates alike - into the ambit of public international law. ${ }^{1 \% i}$ While this innovation would have been difficult to defend in $1959,{ }^{127}$ it seems appropriate today, for two reasons.

First, it is now well accepted that international law can be chosen as the governing law in contracts involving one or more parties that are not subjects of international law, that is, entities that are not states or international organizations. ${ }^{128}$ This legal develop-

'E' ICJ STArUTE Art. 38(1) (a) -(c). A fourth clause lists judicial decisions and the teachings of publicists, as "subsidiary means for the determination of rules of law."

12 EBRD SFrte.MBER 1994 STCs, supra note 109, \$8.04(b)(v) (B), (C).

123 For the Charter provision establishing the legal personality of the EBRD, see EBRD CILARTrR, supra note 6. Art. 45. Section $8.04(\mathrm{~b})(\mathrm{v})$ of the STCs also reflects some other developments that have occurred since the time that Article 38 of the IC] Statute was first drafted. For example, $\$ 8.04(b)$ (v) (B) reflects the fact that international conventions can give rise to rules of customary international law, a proposition confirmed by the ICJ in the North Sea Continental Shelf Cases (FRG v. Den,; FRG v. Neth.), 1969 ICJ RFP. 3, 42 (Feb. 20).

1:24 Another feature of the EBRD's new dispute resolution provisions that is directly related to the applicable law provision is its adoption of the UNCTTRAL Asbitration Rules. See text at and note 114 supra. Although beyond the scope of this article, several aspects of that topic warrant analysis and evaluation-for example, the merits of selecting the UNCITRAI. Arbitration Rules, the significance of specifying The Hague as the place of arbitration, and the relationship between the provisions of \$8.04 and pertinent EBRD Charter provisions.

ims See text at and notes 82-83 supra.

13 As noted above, it is clear from various provisions of the EBRD's STCs that they apply to all "public sector" loan and guarantec agreements; that is, to all loan and guarantee agreements relating to loans made to or guaranteed by a member. See supra note 107. That the STCs' governing law provisions in particular are applicable to all such agreements, including those made with nonstates, is evident from the wording of $\$ 8.04$. Section 8.04(a), quoted in full in note 113 supra, provides that "[ 1 ]he parties to the Loan Agreement and the Guarantee Agreement shall endeavour to settle any dispute or controversy between them arising out of such agreements or in connection therewith." Section 8.04(b) then makes "any such dispute or controversy"whether arising out of the loan agreement or the guarantee agreement-subject to arbitration and directs the arbitral tribunal to apply public international law as defined therein.

${ }^{167}$ As noted in text at note 80 supra, the view most widely held in 1959 was that an agreement with a nonstate entity as a party could not have international law as its governing law. For the same view expressed in 1956, see Sommers, Broches \& Delaume, supra note 17 , at $\mathbf{4 7 0}$ (noting that national and international tribunals had not supported the view that loans involving both a private sector entity and a state should be governed by international law rather than municipal law). Indeed, it was not entirely beyond dispute in the 1950s that any agreement involving an international organization such as the World Bank-even an agreement with a statecould be governed by international law. Broches devoled quite a few pages in his 1959 lectures to proving that international onganizations, including the World Bank, can (and often are) authorized to enter into agreements governed by international law. See Broches, supra note 2, at 316-38. For a summary of current views on treaty-making powers of international organizations, sec BrownLte, supra note 120, at 683-84. See also Delaume, CONTRaCTs, supta note 89, \$1.11.

${ }^{1: *}$ For discussions indicating that international law can be chosen as the governing law in contracts involving at least one party that is not a subject of international law (i.e., at least one party that is not a state or an intemational organization), see Mettala, supra note 48, at 240-41 (noting that even "a private lender and a private borrower could also choose public international law to govern their loan agreement," although certain obstacles present as of $\mathbf{1 9 8 6}$ would probably dictate against widespread use of that option). For many years, certain types of contracts between states and private parties, including oil concession contracts, have often included provisions designating international law as the governing law. See Fernando R. Tesón, State Contracts 
ment reflects in part the growing emphasis on party autonomy in the selection of governing law provisions. ${ }^{1 \times 9}$

Second, the body of "public international law" is now substantial and extensive enough, at least as it is broadly defined in the EBRD's STCs, ${ }^{130}$ to serve as the governing law for an MDB's public sector loan and guarantee agreements. That body of law includes formally promulgated rules on treaty interpretation; ${ }^{131}$ the binding character, formation, validity and performance of both treaties ${ }^{132}$ and contracts; ${ }^{133}$ and commercial and financial terms used in international transactions. ${ }^{134}$ It also includes rules deriving from the operations of the MDBs themselves, such as formal guidelines on the procurement of goods and services for MDB-financed projects; ${ }^{195}$ written interpretations of their own

and Oil Expropriations: The Aminoil-Kuwait Artitration, 24 VA. J. INT"'. L. 323, 324 (1984). See also Delaume, Applicable Law, supra note 89 , at 322 . Delaume points out that the availability of international law as the governing law for an agreement involving one party lacking personality in international law was influenced by Article 42 of the Convention on the Settlement of Investment Disputes between States and Nationals of Other States, Mar. 18, 1965, 17 UST 1270, 575 UNTS 159 (entered into force Oct. 14, 1966). Delaume, supra, at 322 (noting that while Article 42 of the ICSID) Convention applies only to foreign investments, it illustrates the wider principle that any "international person in its relations with domestic law persons [has] the authority to contract under [international law]").

'è Met Mála, supra note 48, at 228-29 (noting that, although some limitations do exist, "[t]he autonomy of the parties to choose the law governing their agreement is . . accepted as the basic rule in almost all jurisdictions."). See also Di:tAUMt, CoNTRACTs, supra note $89, \$ 1.01$ (noting that in general "the parties to transnational contracts enjoy a large degree of autonomy in selecting the [governing law]"); NAN13A, supra note 48, \$5.03[1], at 5-101, 5-102, \$5.03[3][a], at 5-126,5-127, \$5.03[3][b], at 5-131 (noting the acceptance of party autonomy in selecting governing law under U.S. law, under the EC Convention on the Law Applicable to Contractual Obligations, and under the laws of certain other countries). The UNCITRAL. Arbitration Rules, supra note 114, expressly uphold the principle of party autonomy. Article 33 provides that "[t]he arbitral tribunal shall apply the law designated by the parties as applicable to the substance of the dispute."

Is: For the sources of public international law enumerated in $\$ 8.04(\mathrm{~b})$ of the EBRD's STCs, see text at note 119 supra.

tsi See, e.g., 1969 Vienna Convention, supra note 68, Arts. 31, 32; Vienna Convention on the Law of Treaties between States and International Organizations or between International Organizations, Mar. 21, 1986, Arts. 31, 32. UN Doc. A/CONF.129/15, 25 ILM 543 (1986) (not yet entered into force) [hereinafter 1986 Vienna Convention ]. A loan agreement between an MDB and an entity other than a state is not a treaty, if the usual definition of "treaty" is used. Ser, e.g., id., Art. 2(1) (a) (defining "treaty" as requiring that all parties thereto are either states or international organizations). However, a loan agreement between an MDB and a state is a treaty, and therefore is subject to the rules on treaty interpretation appearing in the two Vienna Conventions on treaties, which are generally considered to codify custom in most respects. See Micitari. Akfiuurst, A MODERN INTRODUCTION TO INTERNATIONA. LAW 123 (6th ed. 1987) (noting that most provisions in the 1969 Vienna Convention codify customasy international law). Accord, Bkowntse, supra note 120, at 604 . It seems logical to interpret the terms as they appear in an MDB loan agreement with a state the same when they appear in identical form in an MDB loan agreenent with an entity other than a state.

s: Ser, e.g., 1969 Vienna Convention, supra note 68, Arts. 7-18, 26-27, 42-62; 1986 Vienna Convention, supra note 131, Arts. 7-18, 26-27, 42-62.

${ }^{113}$ See, e.g., International Institute for the Unification of Private Iaw, UNiDRorT Principles of International Commercial Contracts, Arts. 1.3, 2.1-2.22, 3.1-3.20, 6.1.1-6.2.3 (1994) [hereinafter UNIDROIT Principles],

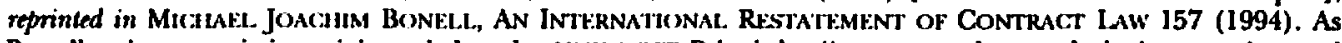
Bonell points out, it is anticipated that the UNIISOIT Principles "may . . . play a role in interpreting and supplementing international instruments." See id. at 110. Rules governing international contracts also appear in the United Nations Convention on Contracts for the International Sale of Coods, Apr. 11, 1980, UN Doc. A/CONF.97/18, 19 ILM 668, 671 (1980) (entered into force Jan. 1, 1988) [hereinafter CISG]. The UNIDROIT Principles, supra, Arts. 4.1-4.8, include rules on contract interpretation similar to those of treaty interpretation given in the 1969 and 1986 Vienna Conventions. For the less comprehensive, but generally similar, rules of contract interpretation appearing in the CISG, sufra, sec Arts. 8, 9.

${ }^{134}$ Ser, e.g., International. Cilamber of Commerci, Pur. No. 500, Uniform Customs and Practicf: for Documeniaky Credtrs (rev. 1994); Inteknationat. Cilamber of Commerce, Incotrekms 1990 (1990) (a set of internationally consistent commercial terms setting forth allocation of costs, risks and functions to be undertaken by parties to international sales transactions). Some general principles applicable to contracts for civil works projects, a mainstay of MDB lending, appear in the F1DIC: conditions of contract. See Fédération Internationale des Ingénieurs-Conseils, Conditions of Contract (International) for Works of Civil Engineering Construction (3d ed. 1977), reprinted in 2 Commercial. ThansaCtions, supta note 89, at 421 .

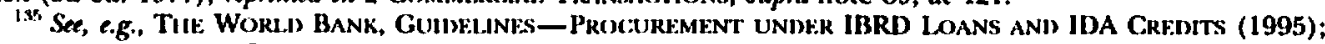

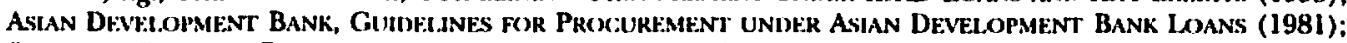

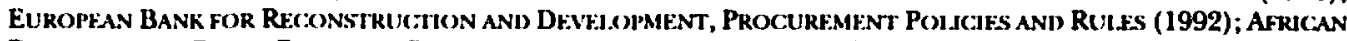

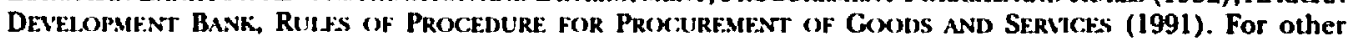


loan, guarantec, and project agreements; ${ }^{196}$ and principles drawn from customary MDB practice in applying and enforcing key provisions of those agreements. ${ }^{137}$ At a time when MDBs are undertaking dramatic changes in the transparency and public accountability of their operations, ${ }^{13 \mathrm{H}}$ the corpus of these MDB-specific rules, both written and customary, can be expected to grow quickly.

In sum, the EBRD's standard provisions on enforceability and dispute resolution constitute both an adoption of and a departure from the traditional World Bank approach. Section 8.01 of the EBRD's STCs insulates the loan agreement and guarantee agreement generally from local law-providing, in essence, that local law is not the governing law for those agreements-and section $\mathbf{8 . 0 4}$ goes further to provide that international law shall always serve as the governing law for purposes of arbitrating disputes arising under such agreements, whether or not the other party to that agreement is the state.

\section{Assessment and Concluding Observations}

The new approach currently taken in the EBRD's STCs relating to the governing law for public sector loan and guarantee agreements has much to recommend it. As explained above, the two pertinent provisions clearly support the status of all such agreements as being governed by public international law, ${ }^{139}$ whether or not the borrower is a state. This is an advantage over previous MDB practice because it more accurately reflects the current reach of public international law and because it puts all these agreements on the same legal foundation, subject to scrutiny under a single set of rules. Most important, it affords greater certainty with regard to the nature of the governing law and the procedures and standards by which disputes are to be resolved.

Perhaps an example will serve to illustrate how this new approach could make an important difference in the relations between an MDB and its borrowers and member states. Assume the following facts. In 1995 an MDB approves a loan for the expansion of a coal-fired power plant in state $A$. The borrower is company $X$, a power corporation that is wholly owned by state $A$. State $A$ is the guarantor. In 1997 a dramatic change in the government of state $A$ brings to power a regime that is ideologically hostile to foreign investment and development assistance.

The new government decides to challenge several aspects of the loan arrangements. First, the government imposes a special charge on the payment of interest due on the loan, so that the state-owned entity makes a smaller net payment to the MDB than is provided for in the loan agreement. Second, the government prohibits the MDB's staff

references to World Bank procurement policies, see supra note 13. Other international organizations have also developed formal rules on procurement. See, e.g., United Nations, Common Principles and Practices Coveming Procurement of Coods and Services by the United Nations System of Onganizations, reprinted in UNITED NATIONS DrvH:L op-

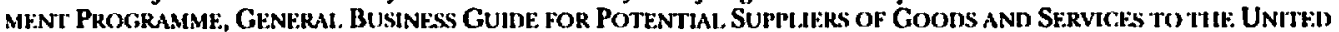
NATIONS SYSTEM 73-86 (1lth ed. 1991).

${ }_{1.3 \%}$ Most MDBs have published extensive sets of rules in the form of operational manuals that explain, among other things, various policies reflected in loan and guarantee agreements. Some of these sets of rules and explanations, including the entire World Bank operational manual, are publicly available. See, e.g., WB Ore.R. MAN., supra note 12, at OP 7.01 (July 1994) (explaining use of covenants in World Bank loan agreements, including covenants on procurement), OP 7.20 (July 1994) (explaining security arrangements, including the use of negative pledge clauses).

${ }^{137}$ For an example of how such customary practice might bear on the interpretation of various provisions of MDB loan agreements, including those governing suspension of loan disbursements in "extraordinary" circumstances, see infra part $\mathrm{V}$.

${ }_{134}$ See, e.g., WB 1994 RisokT, supra note 8, at 74, 75 (noting the establishment of an independent Inspection Panel to investigate complaints that the World Bank has not followed its own policies and procedures on design or implementation of projects, and noting the establishment of a Public Information Center to provide public access to World Bank documents, including appraisal reports and evaluation reports).

${ }^{1.94}$ Further support for this view of the status of such agreements might come from registering them with the United Nations. That subject is beyond the scope of this article but does warrant consideration. An obvious starting point for such consideration would be the World Bank practice and Broches's explanation of it. See text at and notes 57,61 supra. 
members from visiting the power plant concerned, allegedly on grounds that such visits could compromise national security interests. Third, the government orders company $X$, the borrower, to sell a large portion of its assets and remit the proceeds to the state treasury, leaving company $X$ weak financially and institutionally. Fourth, the government orders company $X$ to relax its environmental protection measures associated with the power plant, so that the operation and expansion activities of the plant meet local environmental standards but not those expected by the MDB. Fifth, the government orders that, in awarding all future supply contracts for the plant's expansion, company $X$ must follow procurement procedures recently adopted by a regional trading bloc of countries that have agreed to give each other preferential treatment in bidding for government contracts.

Each of these actions by the government of state $A$ could have legal ramifications under the loan and guarantee agreements relating to the power plant project. Those agreements probably would incorporate standard provisions (1) disallowing the imposition of "any taxes" on the making of interest payments under the loan; ${ }^{10}$ (2) requiring state $X$ to afford "all reasonable opportunity" for the MDB's staff members to visit the project site: ${ }^{141}$ (3) permitting the MDB to suspend disbursements under the loan if an "extraordinary situation" arises that makes it improbable that the project will be carried out or that the borrower or the guarantor will be able to perform its obligations under the loan or guarantee agreement; ${ }^{142}$ (4) requiring the MDB-financed project to be carried out "in accordance with sound environmental . . . standards;" and (5) requiring all goods financed under the MDB loan to be purchased in accordance with the MDB's procurement rules, ${ }^{144}$ with the terms of the loan agreement taking priority over "the law of any State or political subdivision thereof to the contrary." "1.5,

Each of those provisions in the agrcements is open to interpretation. Does the term "any taxes" include a "charge" on interest payments? What is a "reasonable opportunity" to visit a project site? When is a situation "extraordinary" enough to warrant suspension of loan disbursements? How stringent must environmental protection measures be to qualify as meeting "sound" standards? Should the term "law of any State or political subdivision thereof" be construed to include rules deriving from a regional agreement between neighboring states?

Without a clear provision on governing law in the MDB's loan and guarantec agreements with borrower $X$ and state $A$, the answers to these questions of interpretation are fraught with uncertainty. On the other hand, with public international law specified as the governing law, the interpretation of these terms becomes much less uncertain. For instance, it becomes unnecessary to consider the wide array of possible approaches

\footnotetext{
1411 For examples of such standard provisions, see IBRD 1985 GeNrRMI. CondTIONS, supra note 14 , \$8.01 (a): ADB 1986 LOAN REGULATIONS, supra note 93, \$7.01(a)(i); EBRD StirtFMBER 1994 STCs, supra note 109. \$6.01 (a) (i); AFDB 1989 GF.NłRAI. CONDmONS, supra note 93, \$11.02(a).

it' For examples of such standard provisions, see IBRD 1985 Genkral. Condmons, supra note 14, $\$ 9.01$ (c): ADB 1986 IonN Regulations, supra note 93, \$6.04; EBRD Sertemiti 1994 STCs, supra note 109, \$5.02(b): AFDB 1989 Giniral. Conmtions, supra note $93, \$ 12.08(e)$.

${ }^{142}$ For examples of such standard provisions, see IBRD 1985 Ginl:kN. Conimrnons, supra note 14, \$6.02(c); ADB 1986 LoAN REgulati(ons, supra note 93, \$8.02(f); EBRD Stirtrimser 1994 STCs, supm note 109. $\$ 7.01$ (a)(vi); AFDB 1989 GiNkikA. CONDTTUNS, supra note 93, \$8.01 (d).

it3 See EBRD SE:TTEMBEK 1994 STCs, supra note 109, \$4.02(a). For a reference to how the increased concern over environmental effects of MDB-financed projects has been reflected in the loan agreetnents of the World Bank and the ADB, see Astan Divflopment Bank, Entironment Papter No. 10, Envikonsmantal. Loan

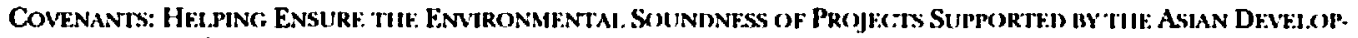
MENT BANK 9-27 (1992).

${ }^{1+1}$ See supra note 13 .

145. For examples of such standard provisions, see text at note 47 supra (quoting the pertinent World Bank provision): text at note 111 supra (quoting the corresponding but slightly broader EBRD provision); ADB

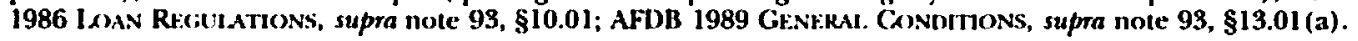


to treaty and contract interpretation, ranging from a strictly textual approach ${ }^{146}$ to a policy-oriented one. ${ }^{147}$ Instead, the proper method of interpretation is probably the contextual approach generally accepted in public international law via the 1969 Vienna Convention on the Law of Treaties. ${ }^{148}$ In addition, guidance on some of the issues, such as what constitutes a set of "sound" environmental standards, could be drawn from customary international law, as reflected in a growing body of treaties and state practice. ${ }^{1.9}$ Moreover, if public international law is defined for these purposes to include rules emerging from the customary practice of international financial institutions, ${ }^{150}$ the positions that the MDBs have taken in the past in interpreting the terms at issue - "any taxes," "reasonable opportunity," and so forth-could be persuasive in settling the dispute between state $A$ and the MDB in the foregoing example, or in preventing the dispute from arising in the first place.

Indeed, the value of a clear provision on governing law for MDB loan and guarantee agreements stems more from its role in the prevention of disputes than from its role in the adjudication of disputes. If the agreements relating to the power plant loan in the foregoing example have clearly specified from the outset that they will be governed by the rules of public international law, including customary rules deriving from the practice of international financial institutions, the government of state $A$ will be less likely to take action inconsistent with those rules. ${ }^{151}$ In short, a clear and effective provision on governing law can prevent disputes by bringing greater certainty to the legal obligations of the parties. ${ }^{152}$

\footnotetext{
Ith See, eg., Emwaki) Sianko Yambrisic, Trfaty Interpretation-Thfioky ani) RfalirTy 9-10 (1987) (explaining the "clear sense" approach, under which it is often not permissible to look beyond the word being interpreted in order to examine its context or the intention behind its use).

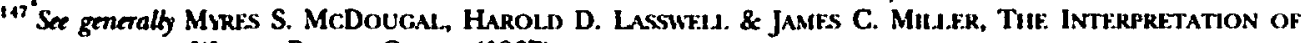
AGiRfEMitiNTS AND WORL.D PUBLIC ORDER (1967).

Itw See 1969 Vienna Convention, supra note 68, Arts. 31, 32. See also text at and notes 131, 133 supra. For a comparison of these three competing approaches to treaty interpretation, see BURNS H. WESTON, RICILARD A. Fal.K \& ANTIONY D'AMato, International. LaW' ant Woria Ordfr. 59-63 (1990).

$11^{4 y}$ For examples of the quickly growing body of international environmental law, see generally UNrTED Nations Envikonment Programige, Multilateral. Trfatifs in tilf: Fift.d of thit. Environment (Iwona Rummel-Bulska \& Seth Osafo eds., 1991); Basic Documents of INTFrnational. ENVIRonmental. LAW (Harald Hohmann ed., 1992).

130 As noted in text at note 119 supra, the EBRD's STCs do that by referring to custom arising from "the practice of . . . international financial institutions."

is) The preventive role of a provision specifying public international law as the governing law could be important also when a borrower or guarantor is contemplating more hostile action than those posited in the foregoing example. For instance, state $A$ might consider declaring that the loan and guarantee agreements are null and void - and that state $A$ and company $X$ are relieved of all their financial obligations thereunderon grounds that those agreements were entered into under a predecessor government and hence are no longer binding. Without a clear provision on governing law, there is little to prevent the government (or an arbitral tribunal or court, if the case were to proceed that far) from choosing any one of a range of theories regarding state succession. On the other hand, with a clear prescription of public international law as the governing law, the likelihood of such an outcome is reduced. See, e.g., 2 Wool), supra note 89, \$4.10[2] (Feb. 1984) (noting the divergence of opinions among states on succession to debt claims; then pointing out the gradual development of rules of public international law on the subject as a result of the International Law Commission's work on treaties governing state succession).

${ }^{132}$ Another factor - a member state's desire for a continuing flow of MDB loans-serves as a powerful incentive to prevent disputes or to dissolve them informally. For references to this important practical consideration, see W. Paatii Ofosu-Amaah, The World Bank-Legal Aspects of Its Recent Lending Activities, in 2 Commercias. Trunsactions, supra note 89, at 305, 309 (noting that "[t] he main sanction that the [World] Bank maintains [to prevent the borrower from acting contrary to the bank's expectations under a loan agreement] is the ability not to extend further loans or credits to such a borrower."); ASLAN DEVklopment Bank, supra note 143, at 57-58 (explaining in the context of ADB operations the practice of "quasi-conditionality," which is "the practice by which the Bank requires covenants associated with one loan to be honored [to the satisfaction of the ADB] before the processing of another loan can be advanced or completed"). However, the existence of this practical consideration, stemming from the usually superior bargaining position of an MDB, does not diminish the importance of establishing legal certainty as a means of preventing disputes from arising between the MDB and its borrowers.
} 
Bringing greater certainty to these issucs also serves a larger purpose: that of evaluating and improving the MDBs. As noted above, the MDBs face increasing scrutiny and criticism. ${ }^{153}$ That is natural, given the growth in their lending volumes ${ }^{154}$ and their corresponding influence in the international economic system. Indeed, whether one agrees or disagrees with particular criticisms, it seems beyond doubt that a close and critical evaluation of MDB operations-on economic, political, environmental and social grounds-is a valuable and productive exercise, for it can yield improvements in those operations.

However, there is nothing to gain, and much to lose, when MDBs unnecessarily leave their operations open to challenge on legal grounds. This is what the MDBs (with the exception now of the EBRD) do by retaining vague provisions on governing law in their loan and guarantee agreements. That vagueness invites legal challenge and dispute on a wide range of issues, as the foregoing example illustrates.

Such legal challenge and dispute, in turn, can undermine support for the MDBs in the international community, especially in the member states that provide the most financial backing for them. ${ }^{155}$ Governments of those states would be unlikely to continue that backing if borrowers did in fact start challenging or circumventing expectations on such things as environmental standards ${ }^{156}$ and procurement procedures. ${ }^{157}$

This outcome would be quite unfortunate, not necessarily because of the result itself (undermining support) but because of the reason for it. The MDBs, like the other major economic and trade institutions that have arisen since World War II - the International Monetary Fund (IMF) and the World Trade Organization (established recently on the foundations of the General Agreement on Tariffs and Trade and its aborted predecessor, the International Trade Organization) $)^{15 *}$ - are founded on the principle that overall public benefit is served by facilitating open market-oriented economic decisions and increasing international transactions. ${ }^{15 \%}$ We cannot fairly judge the effectiveness of the World Bank and other such institutions in pursuing that principle if their operations are derailed for extrancous reasons.

The risk of derailment is greater in respect of MDB operations in the former Soviet republics than it has been so far anywhere else in the world. Much of the harshest

\footnotetext{
${ }^{153}$ See text at notes 7-10 supra. For a recent example of scrutiny of the AFDB, sec Development Banking: Double Trouble, ECONOMIST, May 14, 1994, at 81 (referring to an external report criticizing the AFDB for having a top-heavy bureaucracy riddled with political intrigue, and for haphazard monitoring of loans).

${ }_{15}$ For information on cumulative lending volumes of the MDBs, see text at and note 94 supre. Annual lending by the MDBs recently amounted to about $\$ 35$ billion. See Head, Contracting, supra note 12, at $43-44$.

${ }^{155}$ On the capital subscriptions of $G-7$ states, as reflected in voting rights, see supra note 8.

1.5. For an illustration of the importance placed by the U.S. Congress on environmental sustainability of MDB-financed projects, see the International Development and Finance Act of 1989, Pub. L. No. 101-240, tit. V. \$521 (a) (codified at 22 U.S.C. $\$ 262 \mathrm{~m}-7$ (a) (Supp. V 1993)) (prohibiting U.S. support for MDB loans unless an environmental impact assessment of the project is undertaken first and submitied to the MDB's governing board).

${ }_{157}$ See supra note 15 . The significance of procurement is illustrated also by the fact that the EBRD's STCs, like the World Bank's General Conditions, expressly authorize the institution to publish information on the contracts awarded under loans it makes, including the nationality of the party to whom the contract was

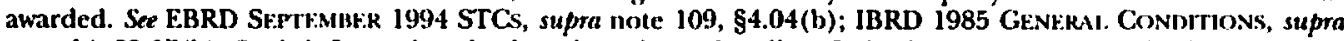
note $14, \$ 9.07$ (b). Such information, broken down by nationality of winning contractors, typically appears in the MDBs' anmual reports. See, e.g., WB 1994 Rtroskr, supra note 8, at 60-63 (showing, e.g., that as of mid1994, U.S. suppliers had been awarded a cumulative total of about $\$ 23$ billion in World Bank contracts).

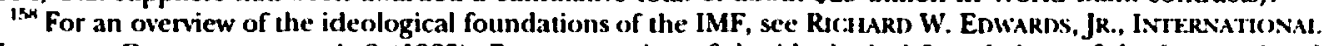
MONETARY COLIABORATION 4-8 (1985). For an oveniew of the ideological foundations of the International Trade Organization, the General Agreement on Tariffs and Trade, and the World Trade Organization, see

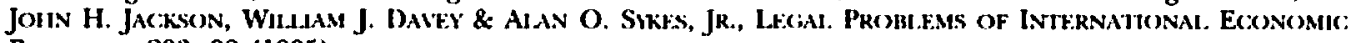
RHLATIONS 293-98 (1995)

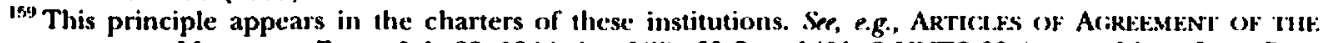
Inteknationat. Monftary Fint), July 22, 1944, Art. I(ii), 60 Stat. 1401, 2 UNTS 39 (entered into force Dec.

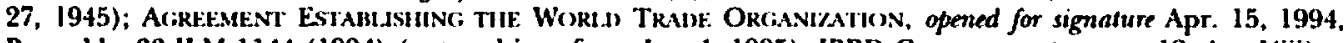
Preamble, 33 ILM 1144 (1994) (entered into force Jan. 1, 1995); IBRI) CilARTF.k, supra note 12, Art. I(iii).
} 
criticism of the World Bank's sister institution, the International Monetary Fund-and much of the threatened or actual suspension of payments to that institution by its borrowing members-occurred just after the IMF dramatically increased its lending to debt-ridden countries caught up in the debt crisis of the early $1980 \mathrm{~s}^{160} \mathrm{Now}$, in the 1990s, the World Bank and the EBRD are lending vast sums of money to public sector borrowers in Central and Eastern Europe and central Asia, ${ }^{161}$ where political and legal stability is tentative at best. It should come as no surprise if some of those borrowers are tempted to renege on those loans in a few years when they start coming due for repayment. ${ }^{162}$ In anticipation of that, it is important and timely that the governing law for the agreements under which the loans are being provided be as clear as possible, and in particular that those agreements be understood to hold the borrowing countries and their state-owned enterprises to international standards.

Isal See John W. Head, Suspension of Debtor Countries' Voting Rights in the IMF: An Assessment of the Third Amendment to the IMF Charter, 33 VA. J. INI"t. L. 591, 598-601 (1993).

Ifit See WB 1994 REPORT, supra note 8, at 230-39 (showing total IBRD and IDA lending as of mid-1994 for the four largest borrowers among the former Soviet republics-Belarus, Kazakhstan, Kyrgyzstan and Russiaas nearly $\$ 3.5$ billion, with Russia alone accounting for almost $\$ 2.9$ billion of that total). Although the EBRD's annual report does not distinguish clearly between private sector and public sector loans in reporting on EBRD operations, it can be inferred that the EBRD has made a total of at least ECU 2.19 billion ( $\$ 2.70$ billion) in public sector loans, since total private sector operations (which are often for smaller amounts than public sector loans) account for $62 \%$ of all projects and the total of all EBRD financings is ECU 5.77 billion (\$7.10 billion). See EBRD 1994 Rf.PORT, supra note 6, at 14-15.

16: Typically, public sector loans made by the MDBs have "grace periods" of several years during which no repayment of principal is required, so that repayments under such loans made by those institutions in 1994 are not required until around 1999. See, e.g., WB 1994 REPORT, supra note 8, at 234-38. See also WB OpER. MAN., supra note 12, at OP 3.10, Ann. D (Sept. 1994) (showing 3-5-year grace periods under most IBRD loans and 10-year grace periods under IDA loans). 